\title{
AKTUALISASI NILAI-NILAI PANCASILA DALAM PEMBANGUNAN HUKUM NASIONAL (STUDI KASUS PERDA PROVINSI, KABUPATEN/KOTA DI INDONESIA)
}

\author{
Lusy Liany \\ Fakultas Hukum Universitas YARSI Jakarta \\ E-mail: lusy.liany@yarsi.ac.id
}

\begin{abstract}
ABSTRAK
Pancasila sebagai sumber dari segala sumber hukum terdapat dalam Pembukaan Undang-Undang Dasar Negara Republik Indonesia Tahun 1945 alinea keempat. Ditegaskan dalam Pasal 2 Undang-Undang Nomor 12 tahun 2011 tentang Pembentukan Perundang-undangan. Pada penjelasan pasal 2 disebutkan bahwa Pancasila sebagai dasar dan ideologi negara serta sekaligus dasar filosofis negara sehingga setiap materi muatan peraturan perundang-undangan tidak boleh bertentangan dengan nilai-nilai yang terkandung dalam Pancasila. Maka dari itu, untuk membangun hukum nasional yang berintegritas dan bersinergi diperlukan aktualisasi nilai-nilai Pancasila disetiap sendi-sendi setiap peraturan perundangundangan dan harmonisasi hukum antara hukum yang berasal dari niliai-nilai yang hidup dan berkembang ditengah masyarakat dengan hukum modern yang positivis. Dengan mengaktualisasikan nilai-nilai etika dan moral dari Pancasila disetiap sendi-sendi setiap peraturan perundang-undangan diharapakan terciptanya pembangungan hukum nasional yang berintegritas dan bermoralitas sesuai dengan nilai jati luhur bangsa.
\end{abstract}

Kata Kunci: Pancasila, Nilai-Nilai, Perda

\begin{abstract}
Pancasila as the source of all sources of law is contained in the fourth paragraph of the Preamble to the 1945 Constitution of the Republic of Indonesia. Affirmed in Article 2 of Law Number 12 of 2011 concerning the Establishment of Legislation. In the explanation of article 2 that Pancasila is the basis and ideology of the state as well as the philosophical basis of the state so that the material contained in the regulations must not conflict with the values contained in Pancasila. Therefore, in order to build a national law with integrity and synergy, it is necessary to actualize the values of Pancasila in every joint of every statutory regulation and to harmonize laws that come from values that live and develop in society with modern positivist law. . By actualizing the ethical and moral values of Pancasila, it is hoped that the establishment of a national law with integrity and morality is in accordance with the noble values of the nation.
\end{abstract}

Keywords: Pancasila, Values, Perda 


\section{PENDAHULUAN}

Pancasila bagi masyarakat Indonesia bukanlah suatu hal yang baru dan asing. Pancasila terdiri dari lima sila yang tertuang dalam Pembukaan UUD 1945 Alinea ke-IV dan diperuntukkan sebagai dasar negara Republik Indonesia. Meskipun didalam Pembukaan UUD 1945 tesebut tidak secara eksplisit kata Pancasila sebagai Dasar Negara, namun hal ini dapat dibuktikan dalam sejarah pembentukannya Pancasila itu sendiri sebagai dasar negara. Kesepakatan bangsa menetapkan Pancasila sebagai dasar Negara Kesatuan Republik Indonesia (NKRI) dinyatakan pada 18 Agustus 1945 oleh PPKI pada saat itu. ${ }^{1}$ Pancasila juga merupakan ideologi bangsa yang terlahir dari kebudayaan bangsa Indonesia sendiri yang telah ada jauh sebelum Indonesia merdeka dimana memiliki nilainilai luhur yang tercermin didalam sila-sila Pancasila.

Dewasa ini, membicarakan Pancasila dianggap sebagai keinginan untuk kembali ke kejayaan masa Orde Baru. Bahkan, sebagian orang memandang sinis tehadap Pancasila sebagai sesuatu yang salah. Kecenderungan demikian wajar karena pada masa Orde Baru Pancasila dijadikan sebagai legitimasi ideologis dalam rangka mempertahankan dan memperluas kekuasaan secara masif. ${ }^{2}$ Mengingat perjalanan panjang Indonesia sejak merdeka hingga saat ini, Pancasila juga ikut berproses pada kehidupan bangsa ini. Pancasila dari awal dibentuk sampai saat ini tetap sebagai dasar negara namun interpretasi dan perluasan maknanya ternyata digunakan untuk kepentingan kekuasaan yang silih berganti. Pada akhirnya keluarnya Ketetapan MPR No.XVIII/MPR/1998 tentang Pencabutan Ketetapan MPR RI No.II/MPR/1978 tentang Pedoman Penghayatan dan Pengamalan Pancasila. ${ }^{3}$

Dengan diterbitkannya Ketetapan MPR tersebut, bertujuan agar tidak terjadi lagi kesalahan dalam memperlakukan Pancasila dalam konteks kehidupan berbangsa, bernegara dan bermasyarakat. Bukan berarti mematikan nilai-nilai Pancasila itu sendiri dan diharapkan jangan sampai Pancasila hanya sebagai lips service berbagai pihak, akan tetapi nilai-nilainya tidak lagi diterapkan. Kaelan menyatakan bahwa perlunya aktualisasi Pancasila, baik aktualisasi Pancasila

\footnotetext{
${ }^{1}$ Winarno, Pendidikan Kewarganegaraan, (Jakarta, Bumi Aksara, 2006), hlm. 1.

${ }^{2}$ Winarno, Op.Cit, hlm.1.

${ }^{3}$ Ibid.
} 
secara subjektif yaitu realisasi nilai-nilai Pancasila pada setiap individu maupun aktualisasi objektif yaitu realisasi dalam segala aspek kenegaraan dan hukum. ${ }^{4}$

Menempatkan Pancasila sebagai dasar dan ideologi negara serta sekaligus dasar filosofis negara sehingga setiap materi muatan Peraturan Perundangundangan tidak boleh bertentangan dengan nilai-nilai yang terkandung dalam Pancasila. ${ }^{5}$ Konsekuensinya, nilai-nilai Pancasila sewajibnya harus menjadi sumber segala peraturan perundang-undangan di Indonesia baik aturan yang bersifat formal maupun informal. Pengamalan nilai-nilai Pancasila dapat dilakukan dengan dua cara, yaitu pengamalan secara objektif dengan melaksanakan dan menaati peraturan perundang-undangan sebagai norma hukum negara yang berlandaskan Pancasila dan pengamalan secara subjektif dengan menjalankan nilai-nilai Pancasila yang berwujud norma etik secara pribadi atau kelompok dalam bersikap dan bertingkah laku pada kehidupan berbangsa, bernegara dan bermasyarakat. ${ }^{6}$

Setiap orang pasti bertanya-tanya termasuk Anda, benarkah Pancasila itu diperlukan sebagai dasar Negara. Apa buktinya jika Pancasila itu perlu dijadikan dasar negara Indonesia.Untuk menjawab pertanyaan tersebut kita akan mulai dari analogi terlebih dahulu. Pancasila seperti jalan aspal yang memberikan arahkemana kendaraan itu dapat dibawa tanpa ada kerusakan. Berbeda dengan jalan yang tidak diaspal, meskipun kendaraan dapat berjalan tetapi dalam waktu yang singkat kendaraan Anda akan cepat rusak. Berdasarkan latar belakang permasalahan yang penulis ungkapkan, maka dapat ditarik beberapa rumusan masalah sebagai berikut: Bagaimana kedudukan Pancasila dalam sistem hukum di Indonesia? Bagaimana aktualisasi nilai-nilai Pancasila dalam Perda Provinsi,Kabupaten/Kota di Indonesia Tahun 2014-2019?

${ }^{4}$ Kaelan MS, Filsafat Pancasila, (Yogyakarta, Paradigma, 2002), hlm.21. Undangan.

${ }^{5}$ Penjelasan Pasal 2 UU No. 12 Tahun 2011 tentang Pembentukan Peraturan Perundang${ }^{6}$ Winarno, Op.Cit, hlm.28. 


\section{METODE PENELITIAN}

Jenis penelitian yang digunakan oleh penulis dalam penyusunan penulisan ini adalah penelitian hukum yuridis normatif. Penelitian yang biasa disebut dengan pendekatan perundang-undangan (Statute Approach) pendekatan kasus (Case Approach), dan pendekatan konseptual (Conceptual Approach) ${ }^{7}$ yang mana penelitian terhadap bahan pustaka atau menggunakan data sekunder. ${ }^{8}$ Penelitian yang dilakukan adalah bersifat deskriptif. Dalam melakukan penelitian ini, sumber data yang penulis gunakan adalah dengan menggunakan data sekunder, yang terdiri dari bahan hukum primer, berupa peraturan perundang-undangan yang terkait dengan penelitian antara lain yaitu, UUD NRI Tahun 1945, Undang Undang Dasar Negara Republik Indonesia Tahun 1945, Undang-Undang Nomor 12 Tahun 2011 tentang Pembentukan Peraturan Perundang-Undangan, UndangUndang Nomor 23 Tahun 2014 tentang Pemerintah Daerah, bahan hukum sekunder berupa semua publikasi tentang hukum yang bukan merupakan dokumen-dokumen resmi. Publikasi tentang hukum meliputi buku-buku teks, kamus-kamus hukum, jurnal-jurnal hukum dan komentar-komentar atas putusan Pengadilan; ${ }^{9}$ dan bahan hukum tersier berupa bahan yang memberikan petunjuk maupun penjelasan terhadap bahan hukum primer dan bahan hukum sekunder. Dalam hal ini, yang digunakan oleh penulis adalah berupa kamus dan berbagai sumber dari situs internet.

\footnotetext{
${ }^{7}$ Peter Mahmud Marzuki, Penelitian Hukum, (Jakarta: Prenadamedia Group, 2016), hlm
} 136.

${ }^{8}$ Soerjono Soekanto, Pengantar Penelitian Hukum, cet 3, (Jakarta : Universitas Indonesia, 2014), hlm. 42.

${ }^{9}$ Peter Mahmud Marzuki, op. cit., hlm. 181. 


\section{PEMBAHASAN}

\section{A. Kedudukan Pancasila Dalam Sistem Hukum Di Indonesia}

Pancasila merupakan sumber segala sumber hukum negara. ${ }^{10}$ Penempatan Pancasila sebagai sumber dari segala sumber hukum negara adalah sesuai dengan Pembukaan Undang-Undang Dasar Negara Republik Indonesia Tahun 1945 alinea keempat. ${ }^{11}$ Pancasila merupakan dasar negara Republik Indonesia terdapat pada Pembukaan Undang-Undang Dasar Negara Republik Indonesia tahun 1945, yang kelahirannya ditempa dalam proses kebangsaan Indonesia.Selain itu, juga ditegaskan dalam Pasal 2 Undang-Undang Nomor 12 tahun 2011 tentang Pembentukan Perundang-undangan bahwa Pancasila merupakan sumber dari segala sumber hukum negara. Di sisi lain, pada penjelasan pasal 2 tersebut dinyatakan bahwa Pancasila sebagai dasar dan ideologi negara serta sekaligus dasar filosofis negara sehingga setiap materi muatan peraturan perundangundangan tidak boleh bertentangan dengan nilai-nilai yang terkandung dalam Pancasila.

Pancasila adalah substansi esensial yang mendapatkan kedudukan formal yuridis dalam Pembukaan Undang-Undang Dasar Negara Republik Indonesia Tahun 1945. Oleh karena itu, rumusan Pancasila sebagai dasar negara adalah sebagaimana terdapat dalam Pembukaan Undang-Undang Dasar Negara Republik Indonesia Tahun 1945. Perumusan Pancasila yang menyimpang dari pembukaan secara jelas merupakan perubahan secara tidak sah atas Pembukaan UndangUndang Dasar Negara Republik Indonesia Tahun 1945. ${ }^{12}$

${ }^{10}$ Pasal 2 UU No. 12 Tahun 2011 tentang Pembentukan Peraturan Perundang-Undangan.

${ }^{11}$ Penjelasan Pasal 2 UU No. 12 Tahun 2011 tentang Pembentukan Peraturan PerundangUndangan.

${ }^{12}$ Kaelan,Op.Cit, hlm.28. 
Terdapat ilustrasi yang dapat mendeskripsikan tata urutan perundanganundangan di Indonesia :
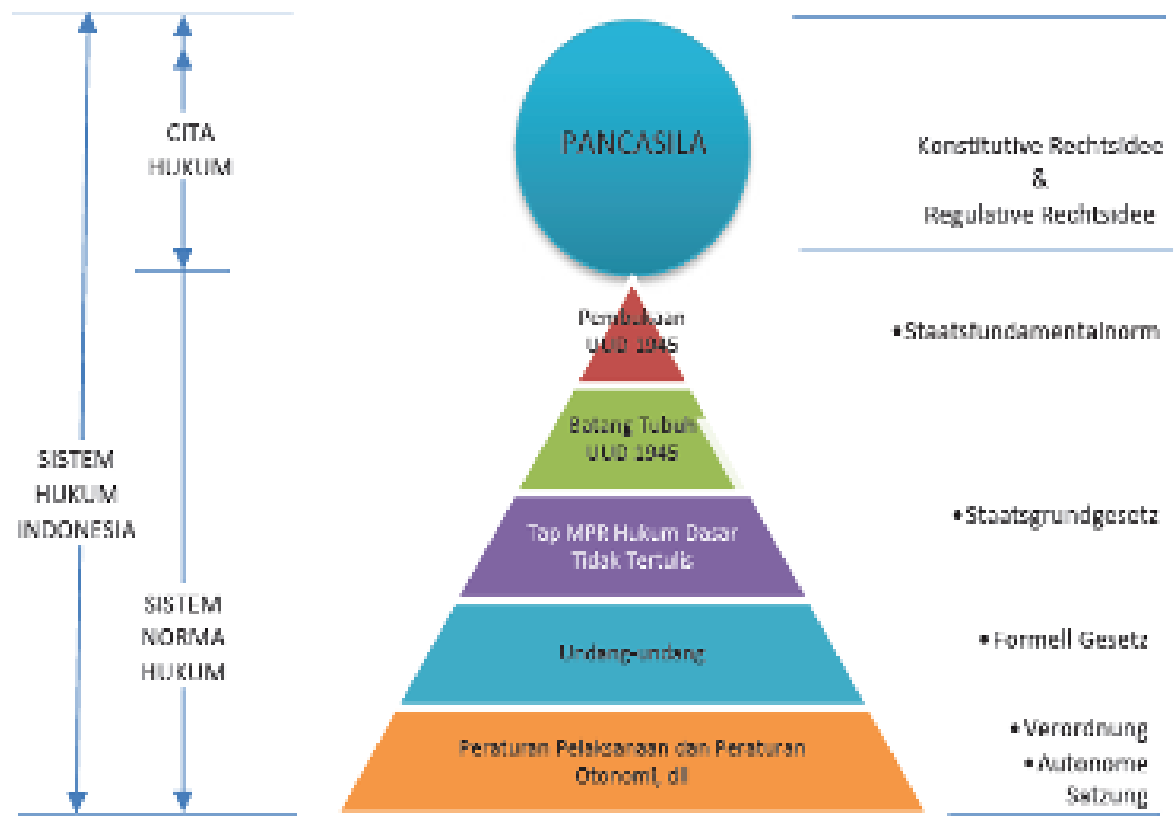

Prinsip bahwa norma hukum itu bertingkat dan berjenjang, termanifestasikan dalam pasal 7 Undang-Undang Nomor 12 tahun 2011 tentang Pembentukan Peraturan Perundang-undangan yang menyebutkan jenis dan hierarki Peraturan Perundang-undangan sebagai berikut:

1) Undang-Undang Dasar Negara Republik Indonesia Tahun 1945;

2) Ketetapan Majelis Permusyawaratan Rakyat;

3) Undang-Undang/Peraturan Pemerintah Pengganti Undang-Undang;

4) Peraturan Pemerintah;

5) Peraturan Presiden;

6) Peraturan Daerah Provinsi; dan

7) Peraturan Daerah Kabupaten/Kota.

Hans kelsen dalam bukunya General Theory Of Law and State (1945) mengemukakan bahwa norma hukum berjenjang-jenjang, berlapis-lapis dalam suatu hierarki tata susunan. Suatu norma hukum selalu yang lebih rendah tidak boleh bertentangan dengan norma hukum yang lebih tinggi, dan norma hukum yang lebih tinggi itu tidak boleh bertentangan dengan norma lain yang lebih tinggi lagi, demikian seterusnya sampai pada suatu norma yang tidak dapat ditelusuri 
lebih lanjut dan bersifat hipotesis dan fiktif yaitu Norma Dasar (Grundnorm). Pendapat Kelsen ini kemudian dikenal dengan Teori Jenjang Norma (Stufentheorie) ${ }^{13}$ Berlakunya norma dasar tidak berdasar lagi, tidak bersumber pada, atau tidak dibentuk oleh norma yang lebih tinggi lagi, tetapi berlakunya ditetapkan terlebih dahulu oleh masyarakat sebagai norma dasar yang merupakan tempat bergantung norma-norma yang berada dibawahnya, sehingga norma dasar dikatakan presupposed. Apabila norma dasar diubah maka akan menjadi rusak sistem norma yang berada di jenjang-jenjang bawahnya. ${ }^{14}$

Pancasila sebagai dasar falsafah negara (dasar filsafat negara) difungsikan untuk mengatur pemerintahan dan mengatur penyelenggaraan negara. Pancasila juga mempunyai fungsi dan kedudukan sebagai pokok atau kaidah negara yang mendasar (fundamental norma). ${ }^{15}$ Kedudukan Pancasila sebagai dasar negara bersifat tetap, kuat, dan tidak dapat diubah oleh siapapun, termasuk oleh MPRDPR hasil pemilihan umum. Mengubah Pancasila berarti membubarkan Negara Kesatuan Republik Indonesia yang diproklamasikan pada tanggal 17 Agustus 1945.

Pancasila Sebagai Dasar Negara tentu harus dipahami karena pancasila merupakan salah satu elemen paling penting dalam negara kita ini. Pancasila sebagai Dasar Negara ialah Pancasila berperan sebagai landasan dan dasar bagi pelaksanaan pemerintahan, membentukan peraturan, dan mengatur penyelenggaraan negara. Pancasila sebagai dasar negara sangat berperan sebagai kacamata bagi bangsa Indonesia dalam menilai kebijakan pemeritahan maupun segala fenomena yang terjadi di masyarakat.

Pancasila sebagai dasar negara menjadikan setiap tingkah laku dan setiap pengambilan keputusan para penyelenggara negara dan pelaksana pemerintahan harus selalu berpedoman pada Pancasila, dan tetap memelihara budi pekerti kemanusiaan yang luhur serta memegang teguh cita-cita moral bangsa. Pancasila sebagai sumber nilai menunjukkan identitas bangsa Indonesia yang memiliki

${ }^{13}$ Maria Farida Indrati, Ilmu Perundang-Undangan, (Yogyakarta: Kanisius, 2016), hlm. 41.

14 Aziz Syamsuddin, Proses dan Teknik Penyusunan Undang-Undang, (Jakarta: Sinar Grafika, 2013), hlm.21.

15 Darji Darmodiharjo dan Sidharta, Pokok-pokok Filsafat Hukum, (Jakarta: Gramedia Pustaka Utama, 1995), hlm. 248-249. 
nilai-nilai kemanusiaan yang luhur, hal ini menandakan bahwa dengan Pancasila bangsa Indonesia menolak segala bentuk penindasan, penjajahan dari satu bangsa terhadap bangsa yang lain. Bangsa Indonesia menolak segala bentuk kekerasan dari manusia satu terhadap manusia lainnya, dikarenakan Pancasila sebagai sumber nilai merupakan cita-cita moral luhur yang meliputi suasana kejiwaan dan watak dari bangsa Indonesia.

Menurut Harun Alrasid kedudukan Undang-undang Dasar bagi suatu negara analog dengan kedudukan anggaran dasar bagi suatu partai politik atau organisasi lainnya, yaitu merupakan pegangan pokok bagi tindakan operasional dari organisasi yang bersangkutan. ${ }^{16}$ Segala aktivitas dan fungsi ormas itu diselaraskan seperti yang telah tertulis dalam anggaran dasar tersebut.Pancasila sebagai dasar negara berfungsi juga sebagai pemersatu bangsa Indonesia, sebagai alat persatuan dan kesatuan, yang di dalamnya merumuskan langsung cita-cita bangsa Indonesia dalam bernegara, yaitu untuk mewujudkan keadilan social bagi seluruh rakyat Indonesia. Cita-cita atau tujuan negara ini dapat menyatukan semua subsistem dalam system social yang ada. ${ }^{17}$ Kedudukan Pancasila sebagai dasar negara dapat dirinci sebagai berikut:

1) Pancasila sebagai dasar negara adalah sumber dari segala sumber tertib hukum Indonesia. Dengan demikian, Pancasila merupakan asas kerohanian hukum Indonesia yang dalam Pembukaan Undang-Undang Negara Republik Indonesia dijelmakan lebih lanjut ke dalam empat pokok pikiran.

2) Meliputi suasana kebatinan (Geislichenhintergrund) dari UUD 1945.

3) Mewujudkan cita-cita hukum bagi dasar negara (baik hukum dasar tertulis maupun tidak tertulis).

4) Mengandung norma yang mengharuskan UUD mengandung isi yang mewajibkan pemerintah dan lain-lain penyelenggara negara (termasuk penyelenggara partai dan golongan fungsional) memegang teguh cita-cita moral rakyat yang luhur.

5) Merupakan sumber semangat abadi UUD 1945 bagi penyelenggaraan negara, para pelaksana pemerintahan. Hal tersebut dapat dipahami karena semangat

\footnotetext{
${ }^{16}$ Harun Alrasid, Naskah UUD 1945 Sesudah Empat Kali Diubah oleh MPR, (Jakarta: Universitas Indonesia (UI-Press), 2007), hlm.150.

${ }^{17}$ Noor Ms Bakry, Pendidikan Pancasila, (Yogyakarta:Pustaka Pelajar, 2014), hlm. 78.
} 
tersebut adalah penting bagi pelaksanaan dan penyelenggaraan negara karena masyarakat senantiasa tumbuh dan berkembang seiring dengan perkembangan zaman dan dinamika masyarakat. ${ }^{18}$

Dalam kehidupan berbangsa dan bernegara, dasar negara Pancasila perlu difahami konsep, prinsip dan nilai yang terkandung di dalamnya agar dapat dengan tepat mengimplementasikannya. Namun sebaiknya perlu diyakini terlebih dahulu bahwa Pancasila memenuhi syarat sebagai dasar negara dari Negara Kesatuan Republik Indonesia dengan beragam suku, agama, ras dan antar golongan yang ada. Pancasila memenuhi syarat sebagai dasar negara bagi Negara Kesatuan Republik Indonesia dengan alasan sebagai berikut: ${ }^{19}$

1) Pancasila memiliki potensi menampung keadaan pluralistik masyarakat Indonesia yang beraneka ragam suku, agama, ras dan antar golongan. Pada Sila Ketuhanan Yang Maha Esa, menjamin kebebasan untuk beribadah sesuai agama dan keyakinan masing-masing. Kemudian pada Sila Persatuan Indonesia, mampu mengikat keanekaragaman dalam satu kesatuan bangsa dengan tetap menghormati sifat masing-masingseperti apa adanya.

2) Pancasila memberikan jaminan terealisasinya kehidupan yang pluralistik, dengan menjunjung tinggi dan menghargai manusia sesuai dengan harkat dan martabatnya sebagai makhluk Tuhan secara berkeadilan yang disesuaikan dengan kemampuan dan hasil usahanya. Hal ini ditunjukkan dengan Sila Kemanusiaan Yang Adil dan Beradab.

3) Pancasila memiliki potensi menjamin keutuhan Negara Kesatuan Republik Indonesia yang terbentang dari Sabang sampai Merauke, yang terdiri atas ribuan pulau sesuai dengan Sila Persatuan Indonesia.

4) Pancasila memberikan jaminan berlangsungnya demokrasi dan hak-hak asasi manusia sesuai dengan budaya bangsa. Hal ini, selaras dengan Sila Kerakyatan yang dipimpin oleh hikmat kebijaksanaan dalam permusyawaratan/perwakilan.

5) Pancasila menjamin terwujudnya masyarakat yang adil dan sejahtera sesuai dengan Sila Keadilan sosial bagi seluruh rakyat sebagai acuan dalam

\footnotetext{
${ }^{18}$ Kaelan,Op.Cit, hlm.98-99.

${ }^{19}$ Ibid.
} 
mencapai tujuan tersebut Pancasila sebagai kaidah negara yang fundamental berarti bahwa hukum dasar tertulis (UUD), hukum tidak tertulis (konvensi), dan semua hukum atau peraturan perundang-undangan yang berlaku dalam negara Republik Indonesia harus bersumber dan berada dibawah pokok kaidah negara yang fundamental tersebut. ${ }^{20}$

\section{B. Aktualisasi Nilai-Nilai Pancasila Dalam Perda Provinsi,Kabupaten/Kota Di Indonesia Tahun 2014-2019?}

Nilai dalam bahasa Latin berasal dari kata Valere yang berarti kuat, baik dan berharga. Nilai adalah sesuatu yang berguna, berharga, dan baik bagi kehidupan manusia. Terdapat tatanan nilai dalam kehidupan bernegara yaitu nilai dasar, nilai instrumental dan nilai praksis. Nilai dasar adalah azas-azas bersifat mutlak yang tidak bisa berubah, hal ini meliputi nilai dasar yang tertuang dalam Pembukaan UUD 1945. Nilai Instrumental adalah pelaksanaan umum dari nilai dasar (Pancasila) yang terwujud dalam norma sosial dan norma hukum. Nilai praksis adalah nilai yang sesungguhnya dilaksanakan dalam kenyataan. Nilai praksis ini akan membuktikan apakah nilai dasar dan instrumental benar-benar hidup dimasyarakat atau tidak. Pancasila merupakan kristalisasi nilai-nilai luhur bangsa Indonesia sejak dahulu kala yang berasal dari nenek moyang bangsa Indonesia sampai kapanpun. Dimana baik nilai dasar ataupun nilai instrumen semuanya bersifat abstrak maka perlu dilaksanakan secara nyata dalam kehidupan sehari-hari. $^{21}$

Berikut nilai-nilai yang terdapat dalam Pancasila, sila pertama : Ketuhanan Yang Maha Esa (Nilai Ketuhanan): ${ }^{22}$

1. Percaya dan takwa kepada Tuhan YME sesuai dengan agama dan kepercayaan masing-masing.

2. Hormat menghormati dan bekerjasama antara pemeluk agama.

3. Saling menghormati dan kebebasan menjalankan ibadah sesuai dengan agama dan kepercayaan masing-masing.

20 Jimly Asshiddiqie, Pengantar Ilmu Hukum Tata Negara, Ed. 1 (Jakarta: PT. RajaGrafindo Persada, 2009),hlm.134.

${ }^{21}$ Suprapto,dkk. Pendidikan Kewarganegaraan. (Jakarta: Bumi Aksara, 2007), hlm. 12. 2014), hlm .21

22 Jakni, Pendidikan Kewarganegaraan Di Perguruan Tinggi, (Bandung: Alfabeta, 
4. Menghargai setiap bentuk ajaran agama dan kepercayaan orang lain.

5. Tidak memaksakan suatu agama dan kepercayaan kepada orang lain.

6. Berhenti saling menyakit, mulailah saling menghargai.

7. Berhenti saling merendahkan, mulailah menghormati perbedaan.

8. Berhenti takabur, mulailah bersyukur.

Sila Kedua : Kemanusiaan Yang Adil dan Beradab (Nilai Kemanusiaan) ${ }^{23}$

1. Mengakui persamaan derajat, persamaan hak dan persamaan kewajiban antara sesama manusia.

2. Saling menyintai sesama manusia.

3. Mengembangkan sikap tenggang rasa.

4. Tidak semena-mena terhadap orang lain.

5. Menjunjung tinggi nilai kemanusiaan.

6. Gemar melakukan kegiatan kemanusiaan diartikan suka sekali melakukan kegiatan kemanusiaan sehingga setiap setiap manusia dapat hidup layak, bebas, dan aman.

7. Berani membela kebenaran dan keadilan.

8. Bangsa indonesia merasa dirinya sebagai bagian dari seluruh umat manusia, karena itu dikembangkan sikap saling menghornati dengan bangsa lain.

9. Stop marah-marah, mulailah bersikap ramah.

10. Berhenti memaki, mulailah memakai hati.

11. Berhenti curiga, mulailah menyapa .

Sila Ketiga : Persatuan Indonesia ${ }^{24}$

1. Menempatkan persatuan, kesatuan, kepentingan serta keselamatan bangsa dan negara diatas kepentingan pribadi atau golongan.

2. Rela berkorban untuk kepentingan bangsa dan negara.

3. Cinta tanah air dan bangsa.

4. Bangga sebagai bangsa Indonesia bertanah air Indonesia.

5. Memajukan pergaulan demi persatuan dan kesatuan bangsa yang ber-Bhinneka Tunggal Ika.

6. Berhenti berseteru, mulailah bersatu.

${ }^{23}$ Ibid, hlm. 24.

${ }^{24}$ Ibid, hlm.26. 
7. Berhenti memaksakan, mulailah berkorban.

8. Berhenti mencari perbedaan, mulailah bergandeng tangan.

Sila Keempat: Kerakyatan yang Dipimpin oleh Hikmat Kebijaksanaan dalam Permusyawaratan/Perwakilan ${ }^{25}$

1. Mengutamakan kepentingan negara dan masyarakat

2. Tidak memaksakan kehendak kepada orang lain

3. Mengutamakan musyawarah dalam mengambil keputusan untuk kepentingan bersama.

4. Dengan itikad baik dan rasa tanggung jawab menerima dan melaksanakan hasil keputusan musyawarah.

5. Berhenti silang pendapat, mulailah mencari mufakat

6. Berhenti besar kepala, mulailah berlapang dada

7. Berhentilah bersilat lidah, mulailah bermusyarah.

Sila Kelima : Keadilan Sosial Bagi Seluruh Rakyat Indonesia ${ }^{26}$

1. Menjaga keseimbangan antara hak dean kewajiban

2. Bersikap adil

3. Menghormati hak-hak orang lain

4. Tidak bersikap boros

5. Tidak bergaya hidup mewah

6. Tidak merugikan kepentingan umum

7. Suka berkerja keras

8. Bersama-sama berusaha mewujudkan kemajuan yang merata dan berkeadilan sosial

9. Berhenti malas, mulailah bekerja keras

10. Stop diskriminasi, mulailah toleransi

11. Berhenti menang sendiri, mulailah berbagi

${ }^{25}$ Ibid, hlm. 28

${ }^{26}$ Ibid, hal.30 
DAFTAR AKTUALISASI NILAI-NILAI PANCASILA

\begin{tabular}{|c|c|c|c|}
\hline NO & $\begin{array}{l}\text { DAFTAR } \\
\text { PERDA }\end{array}$ & PASAL & KETERANGAN \\
\hline 1. & $\begin{array}{l}\text { Peraturan Daerah } \\
\text { Provinsi Banten } \\
\text { Pasal } 3 \text { Tahun } 2016 \\
\text { Tentang } \\
\text { Penyelenggaraan } \\
\text { Ketenteraman, } \\
\text { Ketertiban Umum } \\
\text { Dan Perlindungan } \\
\text { Masyarakat }\end{array}$ & $\begin{array}{l}\text { Pasal 10: } \text { Setiap } \\
\text { orang berkewajiban } \\
\text { menjagaketenteraman } \\
\text { dan ketertiban umum } \\
\text { di Daerah dengan } \\
\text { cara mentaati Perda } \\
\text { dan Perkada. }\end{array}$ & $\begin{array}{l}\text { Menjaga ketenteraman } \\
\text { dan ketertiban umum, } \\
\text { merupakan hal yang } \\
\text { harus diupayakan bersama } \\
\text { oleh masyarakat dan ini } \\
\text { pengamalan sila Ke-2 } \\
\text { Pancasila }\end{array}$ \\
\hline 2. & $\begin{array}{l}\text { Peraturan Daerah } \\
\text { Kabupaten Inagiri } \\
\text { Hulu No. } 9 \text { Tahun } \\
2014 \text { Tentang Tata } \\
\text { Cara Pencalonan, } \\
\text { Pemilihan, } \\
\text { Pelantikan Dan } \\
\text { Pemberhentian } \\
\text { Kepala }\end{array}$ & $\begin{array}{l}\text { Pasal 19 Ayat 1c: Calon } \\
\text { Kepala Desa Yang } \\
\text { Berhak Dipilih Dengan } \\
\text { Melampirkan Surat } \\
\text { Keterangan Dari Kantor } \\
\text { Kementerian Agama } \\
\text { Kabupaten Bahwa Bisa } \\
\text { Membaca Al-Qur'an } \\
\text { Bagi Yang Beragama } \\
\text { Islam." }\end{array}$ & $\begin{array}{l}\text { Menghargai Setiap } \\
\text { Bentuk Ajaran Agama } \\
\text { Dan Kepercayaan Orang } \\
\text { Lain. Serta Pemenuhan } \\
\text { Kewajibannya Sebagai } \\
\text { SeorangMuslimJuga Perlu } \\
\text { MenjadiDilakukanKarena } \\
\text { Akan Menunjukkan Pula } \\
\text { Spiritualitas Dan Iman } \\
\text { Dari Calon Tersebut. dan } \\
\text { ini pengamalan sila Ke-1 } \\
\text { Pancasila }\end{array}$ \\
\hline 3. & $\begin{array}{lr}\text { Peraturan Daerah } \\
\text { Provinsi } \\
\text { Sumatera Selatan } \\
\text { Nomor } 3 \text { Tahun } \\
2015 \quad \text { Tentang } \\
\text { Program } & \text { Kuliah } \\
\text { Gratis } & \end{array}$ & $\begin{array}{lrr}\text { Pasal 3: } & \text { Sasaran } \\
\text { Program Kuliah } & \text { Gratis } \\
\text { adalah lulusan } & \text { SLTA } \\
\text { yang berasal } & \text { dari } \\
\text { Sumatera Selatan dari } \\
\text { keluarga rang } \\
\text { mampu yang diterima } \\
\text { di perguruan tinggi } \\
\text { dengan usia ijazah tidak } \\
\text { lebih dari } 3 \text { (tiga) } \\
\text { tahun. }\end{array}$ & $\begin{array}{l}\text { Memberikan Program } \\
\text { Kuliah Gratis membantu } \\
\text { rakyat agar mendapat } \\
\text { kuliah gratis dalam } \\
\text { rangka Bersama-sama } \\
\text { berusaha mewujudkan } \\
\text { kemajuan yang merata } \\
\text { dan berkeadilan social } \\
\text { dan ini pengamalan sila Ke- } \\
5 \text { Pancasila. }\end{array}$ \\
\hline 4. & $\begin{array}{l}\text { Peraturan Daerah } \\
\text { Kota Bandung } \\
\text { Nomor } 26 \text { Tahun } \\
2009 \text { Tentang } \\
\text { Kesetaraan Dan } \\
\text { Pemberdayaan } \\
\text { Penyandang } \\
\text { Cacat }\end{array}$ & $\begin{array}{l}\text { Pasal 40: Pengusaha } \\
\text { wajib memberikan } \\
\text { kesempatan yang sama } \\
\text { kepada tenaga kerja } \\
\text { penyandang cacat yang } \\
\text { memenuhi persyaratan } \\
\text { jabatan dan kualifikasi } \\
\text { pekerjaan untuk } \\
\text { memperoleh pekerjaan }\end{array}$ & $\begin{array}{l}\text { Tidak membeda-bedakan } \\
\text { satu sama lain antara } \\
\text { penyandang disabilitas } \\
\text { dengan non-disabilitas. } \\
\text { dalam rangka bersama- } \\
\text { sama berusaha } \\
\text { mewujudkan kemajuan } \\
\text { yang merata dan } \\
\text { berkeadilan social dan ini }\end{array}$ \\
\hline
\end{tabular}




\begin{tabular}{|c|c|c|c|}
\hline & & $\begin{array}{l}\text { sesuai dengan jenis dan } \\
\text { derajat kecacatannya. }\end{array}$ & $\begin{array}{lll}\text { pengamalan } & \text { sila } & \text { Ke- } 5 \\
\text { Pancasila. } & & \\
\end{array}$ \\
\hline 5. & $\begin{array}{l}\text { Peraturan Daerah } \\
\text { Kota Serang } \\
\text { Nomor 2 Tahun } \\
\text { 2010Tentang } \\
\text { Pencegahan, } \\
\text { Pemberantasan } \\
\text { Dan } \\
\text { Penanggulangan } \\
\text { Penyakit } \\
\text { Masyarakat }\end{array}$ & $\begin{array}{l}\text { Pasal 10: Setiap orang } \\
\text { dilarang merokok, makan } \\
\text { atau minum di tempat } \\
\text { umum atau tempat yang } \\
\text { dilintasi oleh umum pada } \\
\text { siang hari di bulan } \\
\text { ramadhan. }\end{array}$ & $\begin{array}{l}\text { Saling menghormati dan } \\
\text { kebebasan menjalankan } \\
\text { ibadah sesuai dengan } \\
\text { agama dan kepercayaan } \\
\text { masingmasing dan } \\
\text { Menghargai setiap bentuk } \\
\text { ajaran } \\
\text { agama dan kepercayaan } \\
\text { orang lain ini pengamalan } \\
\text { sila Ke-1 Pancasila. }\end{array}$ \\
\hline 6. & $\begin{array}{l}\text { Peraturan Daerah } \\
\text { Bali Tahun } 2018 \\
\text { Tentang } \\
\text { Kesejahteraan } \\
\text { Lanjut Usia }\end{array}$ & $\begin{array}{l}\text { Pasal 9: Peningkatan } \\
\text { Kesejahteraan Lanjut } \\
\text { Usia meliputi : } \\
\text { a. Pelayanan keagamaan } \\
\text { dan mental spiritual; } \\
\text { b. Pelayanan kesehatan; } \\
\text { c. Pelayanan kesempatan } \\
\text { kerja; } \\
\text { d. Pelayanan pendidikan } \\
\text { dan pelatihan; } \\
\text { e. Kemudahan dalam } \\
\text { penggunaan fasilitas, } \\
\text { sarana, dan prasarana } \\
\text { umum; } \\
\text { f. Kemudahan dalam } \\
\text { layanan dan bantuan } \\
\text { hukum; } \\
\text { g. Partisipasi sosial dan } \\
\text { sipil; } \\
\text { h. Perlindungan sosial; } \\
\text { i. Bantuan sosial; dan } \\
\text { j. Pemberian santunan. }\end{array}$ & $\begin{array}{l}\text { Berisi tentang pemberian } \\
\text { berbagai pelayanan, } \\
\text { perlindungan, bantuan, } \\
\text { serta pemberian fasilitas } \\
\text { yang akan memudahkan } \\
\text { para kaum lanjut usia, } \\
\text { yang mana sesuai dengan } \\
\text { contoh dari nilai praktis } \\
\text { yang mencerminkan sila } \\
\text { ke-5. }\end{array}$ \\
\hline 7. & $\begin{array}{l}\text { Peraturan Daerah } \\
\text { Kabupaten } \\
\text { Trenggalek } \\
\text { Nomor 1 Tahun } \\
2017 \\
\text { TentangPenyelen } \\
\text { ggaraan } \\
\text { Pendidikan }\end{array}$ & $\begin{array}{l}\text { Pasal } 9 \text { ayat (4):Peserta } \\
\text { Didik yang berprestasi } \\
\text { dan/atau yang orang } \\
\text { tuanya tidak mampu } \\
\text { membiayai Pendidikan } \\
\text { berhak mendapatkan bea } \\
\text { siswa dan/atau bantuan } \\
\text { biaya Pendidikan dari } \\
\text { Pemerintah, Pemerintah } \\
\text { Daerah dan/atau } \\
\text { Masyarakat. }\end{array}$ & $\begin{array}{l}\text { Bersama-sama berusaha } \\
\text { mewujudkan kemajuan } \\
\text { yang merata dan } \\
\text { berkeadilan sosial dalam } \\
\text { hal ini mendapatkan } \\
\text { beasiswa bagi mahasiswa } \\
\text { yang tidak mampu ini ini } \\
\text { pengamalan sila Ke-5 } \\
\text { Pancasila. }\end{array}$ \\
\hline
\end{tabular}




\begin{tabular}{|c|c|c|c|}
\hline 8. & $\begin{array}{lr}\text { Perda } & \text { Kabupaten } \\
\text { Nusa Tenggara } \\
\text { Barat Nomor } 2 \\
\text { Tahun } 2016 \\
\text { Tentang } \\
\text { Pariwisata Halal }\end{array}$ & $\begin{array}{l}\text { Pasal 6: Pengelola } \\
\text { Destinasi pariwisata halal } \\
\text { harus r membangun } \\
\text { fasilitas umum untuk } \\
\text { mendukung kenyamanan } \\
\text { aktivitas kepariwisataan } \\
\text { halal. }\end{array}$ & $\begin{array}{l}\text { Saling menghormati } \\
\text { sesuai dengan agama dan } \\
\text { kepercayaan } \\
\text { masingmasing } \\
\text { pengamalan sila Ke-1 } \\
\text { Pancasila. }\end{array}$ \\
\hline 9. & $\begin{array}{l}\text { Peraturan Daerah } \\
\text { Kabupaten } \\
\text { Bangka Nomor } 4 \\
\text { Tahun } 2015 \\
\text { Tentang } \\
\text { Perizinan Bidang } \\
\text { Kesehatan }\end{array}$ & $\begin{array}{l}\text { Pasal 16: pemerintah } \\
\text { daerah berkewajiban : } \\
\text { a.Mewujudkan derajat } \\
\text { kesehatan } \\
\text { masyarakat yang } \\
\text { optimal. } \\
\text { b. Melindunggi } \\
\text { masyarakat terhadap } \\
\text { segala kemungkinan } \\
\text { kejadian yang dapat } \\
\text { menimbulkan } \\
\text { gangguan dan/bahaya } \\
\text { terhadap kesehatan } \\
\text { akibat pelayana di } \\
\text { bidang kesehatan. } \\
\text { c. Memberikan } \\
\text { kemudahan dalam } \\
\text { pelayanan di bidang } \\
\text { kesehatan. } \\
\text { d. Melakukan pengaturan } \\
\text { jumlah dan kepadatan } \\
\text { fasilitas pelayanan } \\
\text { kesehatan di suatu } \\
\text { wilayah untuk } \\
\text { menjamin pemerataan } \\
\text { dan mutu pelayanan } \\
\text { kesehatan dan } \\
\text { e. Memberikan } \\
\text { pembinaan, } \\
\text { pengawasan } \\
\text { pengendalian terhadap } \\
\text { penyelenggaraan } \\
\text { pelayanan kesehatan. }\end{array}$ & $\begin{array}{l}\text { Bersama-sama berusaha } \\
\text { mewujudkan kemajuan } \\
\text { yang merata dan } \\
\text { berkeadilan sosial di } \\
\text { bidang kesehatan ini } \\
\text { pengamalan sila Ke-5 } \\
\text { Pancasila. }\end{array}$ \\
\hline 10. & $\begin{array}{lr}\text { Peraturan } & \text { Daerah } \\
\text { Provinsi Nusa } & \text { Tenggara Barat } \\
\text { Tomor } 4 \text { Tahun } \\
2015 \quad \text { Tentang } \\
\text { Penyelenggaraan } \\
\text { Pendidikan }\end{array}$ & $\begin{array}{l}\text { Pasal } 17 \text { ayat (3): Setiap } \\
\text { Satuan Pendidikan } \\
\text { menerapkan perilaku } \\
\text { religius yang meliputi: } \\
\text { a. kegiatan iman dan } \\
\text { taqwa (imtaq) setiap } \\
\text { hari Jum'at sebelum } \\
\text { jam pelajaran dimulai; }\end{array}$ & \begin{tabular}{lr}
\multicolumn{2}{l}{ Dalam pasal dijelaskan } \\
bahwa ketakwaan \\
terhadap tuhan juga di \\
perlukan & dalam \\
pendidikan & di \\
sekolah,yang & dapat \\
ditunjukkan dengan \\
cara seperti & adanya \\
\end{tabular} \\
\hline
\end{tabular}




\begin{tabular}{|c|c|c|c|}
\hline & & $\begin{array}{l}\text { b. } \text { pakaian seragam yang } \\
\text { mencerminkan } \\
\text { religiusitas, dan } \\
\text { pakaian khusus } \\
\text { keagamaan yang } \\
\text { diberlakukan pada } \\
\text { kegiatan sebagaimana } \\
\text { dimaksud pada ayat } \\
\text { (1); } \\
\text { c. mempersyaratkan } \\
\text { kemampuan baca dan } \\
\text { tulis Al-Qur'an bagi } \\
\text { lulusan satuan } \\
\text { pendidikan dasar dan } \\
\text { menengah yang } \\
\text { beragama Islam dan } \\
\text { peserta didik } \\
\text { nonmuslim } \\
\text { menyesuaikan. }\end{array}$ & $\begin{array}{l}\text { kegiatan imtaq di hari } \\
\text { jum'at,pakaian } \\
\text { seragam yang } \\
\text { mencerminkan religius } \\
\text { atau } \\
\text { sopan,mensyarakatkan } \\
\text { kemampuan baca dan } \\
\text { tulis al-quran. Pasal ini } \\
\text { sesuairyan dengan } \\
\text { pancasila adalah pasal } \\
\text { ini mencerminkan nilai } \\
-\quad \text { nilai pancasila } \\
\text { pertamaryaitu } \\
\text { Ketuhanan Yang Maha } \\
\text { Esar. }\end{array}$ \\
\hline 11. & $\begin{array}{l}\text { Peraturan Daerah } \\
\text { Provinsi Bangka } \\
\text { Belitung Nomor } \\
1 \text { Tahun } 2015 \\
\text { tentang } \\
\text { Penyelenggaraan } \\
\text { Bantuan Hukum } \\
\text { Bagi Masyarakat } \\
\text { Miskin }\end{array}$ & $\begin{array}{l}\text { Pasal } 8 \text { (1) :Setiap orang } \\
\text { miskin atau kelompok } \\
\text { orang miskin yang } \\
\text { berdomisili di Daerah } \\
\text { berhak menjadi Penerima } \\
\text { Bantuan Hukum. } \\
\text { Pasal } 27 \quad(1) \text { :Segala } \\
\text { warga negara bersamaan } \\
\text { kedudukannya di dalam } \\
\text { hukum dan pemerintahan } \\
\text { dan wajib menjunjung } \\
\text { hukum dan pemerintahan } \\
\text { itu dengan tidak ada } \\
\text { kecualinya. }\end{array}$ & 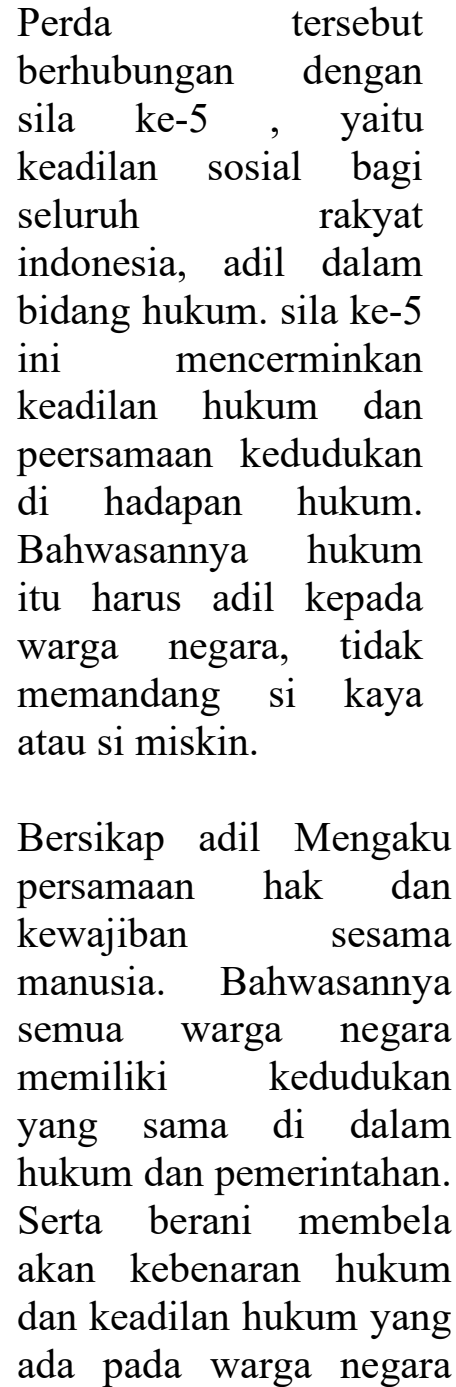 \\
\hline
\end{tabular}




\begin{tabular}{|c|c|c|c|}
\hline & & & $\begin{array}{l}\text { tanpa melihat status, } \\
\text { jabatan, dan miskin atau } \\
\text { kaya nya seseorang ini } \\
\text { pengamalan sila Ke-5 } \\
\text { Pancasila. }\end{array}$ \\
\hline 12. & $\begin{array}{l}\text { Peraturan Daerah } \\
\text { Provinsi } \\
\text { Sumatera Barat } \\
\text { Nomor } 2 \text { Tahun } \\
2015 \text { Tentang } \\
\text { Perlindungan } \\
\text { Dan Pemenuhan } \\
\text { Hak Penyandang } \\
\text { Disabilitas }\end{array}$ & 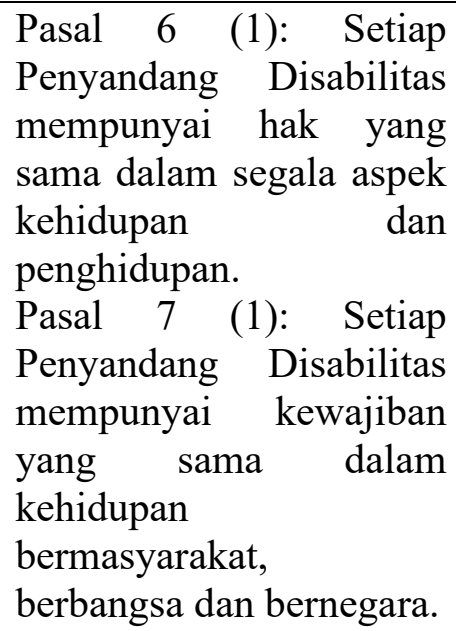 & 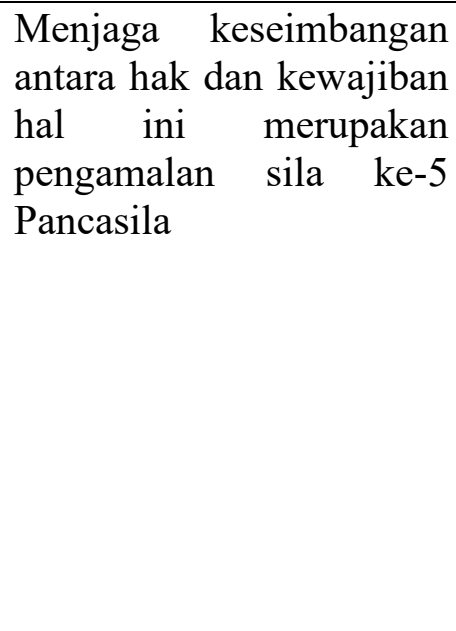 \\
\hline
\end{tabular}

Dalam pembangunan budaya hukum yang khas Indonesia inilah kita harus secara cermat dan hati-hati mmeilih nilai-nilai luhur yang memadai dengan sistem nilaiyang hidup dan diyakini kebenarannya oleh Bangsa Indonesia. Sikap hati-hati dalam pembangunan budaya hukum tersebut dipandang perlu mengingat budaya hukum senantiasa memegang peranan penting dan menentukan bagi bekerjanya sistem hukum secara keseluruhan, sehingga komponen-komponen dalam sistem hukum yaitu substansi, struktur dan kultur saling melengkapi dan mengisi diantara satu dengan yang lainnya. ${ }^{27}$

Budaya hukum yang berisi nilai-nilai luhur yang berisi nilai-nilai luhur yang diyakini kebenarannya oleh segenap komponen bangsa dan bagi bangsa Indonesia, nilai-nilai luhur dimaksud tidak lain adalah nilai-nilai Pancasila itu sendiri. Dan nilai-nilai Pancasila harus menjadi basis yang mengarahkan ide-ide gagasan pandangan dan persepsi dari seluruh komponen masyarakat dalam kehidupan berbangsa dan bernegara.

Pembangunan hukum dalam transformasi berbagai bidang tidak dapat bersifat otonom atau terlepas dari sektor lain, harus senantiasa berkaitan dengan pembangunan pada sektor lain seperti politik, ekonomi, sosial sosial maupun 
budaya. Terkadang seringmenimbulkan kritik tajam yang dilontarkan pada pembangunan hukum yaitu kurang tanggapnya hukum dalam mengantisipasi perkembangan masyarakat hukum yang berubah begitu cepat.Hukum yang ada sejak semula diharapkan menjadi aturan main (rule of game) ternyata tidak mampu berbuat apa-apa bahkan memiliki kecenderungan semakin tertinggal.

Pembangunan hukum mempunyai banyak aspek dan karena itu cukup rumit.Ia tidak hanya meliputi pembangunan perundang-undangan dan struktur melainkan juga perilaku substansial.Pembangunan hukum juga mempunyai hubungan sinergis dengan bidang dan kekuatan lain. Dalam menghadapi perkembangan yang begitu cepat menurut hukum terkesan konsevatif, hukum sering dipahami sebagai polisi yang memelihara security and order.Hukum seringkali berubah kalau nilai-nilai sosial berubah, sekaipun ada juga yang berpendapat dengan menekankan penafsiran hukum sebagai agent of modernization seperti yang dikemukakan oleh Roscoe Pound as an instrument social engiuneering. ${ }^{28}$

Kehadiran hukum ditengah-tengah masyarakat yang jelas menghasilkan berbagai macam pendapat tetapi satu hal yang pasti bahwa hukum itu syarat dengan nilai-nilai sehingga hukum dapat dimaknakan sebagai pencerminan dari nilai-nilai sebab ia lahir untuk mewujudkan nilai-nilai tertentu dalam kehidupan sosial masyarakat. Dalam suatu masyarakat yang sedang membangun maka akan senantiasa dicirikan oleh perubahan, bagaimanapun kita mendefinisikan pembangunan tersebut dan apapun indikator-indikator yang kita pergunakan untuk masyarakat dalam pembangunan, maka peranan hukum dalam pembangunan adalah untuk dapat menjamin agar perubahan yang terjadi dan dialami oleh masyarakat tersebut dapat dilalui dengan cara yang teratur.

Peran serta hukum dalam pembangunan jelas merupakan faktor yang sangat krusial bagi keberhasilan pembangunan, terutama disaat krisis multidimensional yang berkepanjangan maka hukum harus menampakkan wujudnya dengan adanya Politicall will dari pemerintah untuk mengangkat ide supremasi hukum sehingga pada akhirnya hukum dapat berperan sebagai panglima yang diharapkan mampu

\footnotetext{
${ }^{28}$ Ibid. hlm. 57.
} 
menyelesaikan, mengatur segala masalah yang timbul dalam kehidupan amsyarakat, dan menciptakan ketertiban dalam tatanan sosial masyarakat. ${ }^{29}$

\section{PENUTUP}

\section{Kesimpulan}

Pancasila sebagai sumber dari segala sumber hukum terdapat dalam Pembukaan Undang-Undang Dasar Negara Republik Indonesia Tahun 1945 alinea keempat. Ditegaskan dalam Pasal 2 Undang-Undang Nomor 12 tahun 2011 tentang Pembentukan Perundang-undangan. Pada penjelasan pasal 2 disebutkan bahwa Pancasila sebagai dasar dan ideologi negara serta sekaligus dasar filosofis negara sehingga setiap materi muatan peraturan perundang-undangan tidak boleh bertentangan dengan nilai-nilai yang terkandung dalam Pancasila. Maka dari itu, untuk membangun hukum nasional yang berintegritas dan bersinergi diperlukan aktualisasi nilai-nilai Pancasila disetiap sendi-sendi setiap peraturan perundangundangan dan harmonisasi hukum antara hukum yang berasal dari niliai-nilai yang hidup dan berkembang ditengah masyarakat dengan hukum modern yang positivis. Dengan mengaktualisasikan nilai-nilai etika dan moral dari Pancasila disetiap sendi-sendi setiap peraturan perundang-undangan diharapakan terciptanya pembangungan hukum nasional yang berintegritas dan bermoralitas sesuai dengan nilai jati luhur bangsa.

\footnotetext{
${ }^{29}$ Ibid. hlm. 58.
} 


\section{DAFTAR PUSTAKA}

\section{Buku}

Achmad Fauzi,PancasilaDitinjau dari Segi Sejarah-Segi Yuridis Konstitusional dan Segi Filosofis, cet.III (Malang: Lembaga Penerbitan Universitas Brawijaya, 2007

Aziz Syamsuddin, Proses dan Teknik Penyusunan Undang-Undang, (Jakarta: Sinar Grafika, 2013).

Burhan Ashofa, Metode Penelitian Hukum, PT. Rineka Cipta, Jakarta, 2004.

Darji Darmodiharjo dan Sidharta, Pokok-pokok Filsafat Hukum, (Jakarta: Gramedia Pustaka Utama, 1995).

Gunawan Setiardja,Hak-hak Asasi Manusia Berdasarkan Ideologi Pancasila, (Yogykarta: Kanisius, 1993)

Harun Alrasid, Naskah UUD 1945 Sesudah Empat Kali Diubah oleh $M P R$, (Jakarta: Universitas Indonesia (UI-Press), 2007).

Jakni, Pendidikan Kewarganegaraan Di Perguruan Tinggi, (Bandung: Alfabeta, 2014).

Jimly Asshiddiqie, Pengantar Ilmu Hukum Tata Negara, Ed. 1 (Jakarta: PT. RajaGrafindo Persada, 2009).

Kaelan, Filsafat Pancasila, (Yogyakarta: Paradigma, 2002).

Kaelan, Pendidikan Pancasila, (Yogyakara: Paradigma, 2010).

Maria Farida Indrati, Ilmu Perundang-Undangan, (Yogyakarta: Kanisius, 2016).

Maria, SW. Sumardjono, Metodologi Penelitian Ilmu Hukum, (Universitas Gajah Mada, Yogyakarta, 2005).

Noor Ms Bakry, Pendidikan Pancasila, (Yogyakarta:Pustaka Pelajar, 2014). 2004).

Nurcholish Majid, Indonesia Kita, (Jakarta: Gramedia Pustaka Utama,

Utojo Usman, Pancasila sebagai Ideologi: dalam Berbagai Bidang Kehidupan Bermasyarakat, Berbangsa, dan Bernegara, Cet.III (Surabaya: Karya Anda, 2008). 

2007).

Suprapto,dkk. Pendidikan Kewarganegaraan. (Jakarta: Bumi Aksara,

${ }^{1}$ Soejono Soekanto dan Sri Mamudji, Penelitian Hukum Normatif Suatu Tinjauan Singkat, (PT. Raja Grafindo Persada, Jakarta, 2010).

Winarno, Pendidikan Kewarganegaraan Perguruan Tinggi, (Jakarta: Bumi Aksara, 2006).

Zainuddin Ali, Metode Peneliti Hukum,(Sinar Grafika, Jakarta 2011)

Zuhraini, "Revitalisasi Pancasila dalam Pembangunan Hukum Nasional di Era Globalisasi”, (Lampung: Jurnal Pranata Hukum, Vol. 7 No. 1, Januari 2012

\section{Peraturan Perundang-Undangan}

Indonesia, Undang-Undang Dasar Negara Republik Indonesia Tahun 1945.

Indonesia, Undang-Undang Nomor 12 Tahun 2011 tentang Pembentukan Peraturan Perundang-Undangan.

Indonesia, Undang-Undang Nomor 23 Tahun 2014 tentang Pemerintah Daerah: 